\title{
Recombinant Expression of Thrombolytic Agent Reteplase in Marine Microalga Tetraselmis subcordiformis (Chlorodendrales, Chlorophyta)
}

\author{
Chunhui $\mathrm{Wu}^{1,2} \mathbb{D}$, Caiyun Zheng ${ }^{1}$, Jinxia Wang ${ }^{1,2} \mathbb{D}$ and Peng Jiang ${ }^{1,2, * \mathbb{C}}$ \\ 1 CAS and Shandong Province Key Laboratory of Experimental Marine Biology, \\ Center for Ocean Mega-Science, Institute of Oceanology, Chinese Academy of Sciences, \\ Qingdao 266071, China; wuchunhui@qdio.ac.cn (C.W.); caiyun.zheng140205@mail.nwpu.edu.cn (C.Z.); \\ jxwang@qdio.ac.cn (J.W.) \\ 2 Laboratory for Marine Biology and Biotechnology, Qingdao National Laboratory for Marine Science and \\ Technology, Qingdao 266237, China \\ * Correspondence: jiangpeng@qdio.ac.cn
}

check for updates

Citation: Wu, C.; Zheng, C.; Wang, J.; Jiang, P. Recombinant Expression of Thrombolytic Agent Reteplase in Marine Microalga Tetraselmis subcordiformis (Chlorodendrales, Chlorophyta). Mar. Drugs 2021, 19, 315. https://doi.org/10.3390/ md19060315

Academic Editors: Alexandros Tsoupras and Ioannis Zabetakis

Received: 31 March 2021

Accepted: 26 May 2021

Published: 28 May 2021

Publisher's Note: MDPI stays neutral with regard to jurisdictional claims in published maps and institutional affiliations.

Copyright: (c) 2021 by the authors. Licensee MDPI, Basel, Switzerland. This article is an open access article distributed under the terms and conditions of the Creative Commons Attribution (CC BY) license (https:// creativecommons.org/licenses/by/ $4.0 /)$.

\begin{abstract}
Tetraselmis subcordiformis, a unicellular marine green alga, is used widely in aquaculture as an initial feeding for fish, bivalve mollusks, penaeid shrimp larvae, and rotifers because of its rich content of amino acids and fatty acids. A stable nuclear transformation system using the herbicide phosphinothricin (PPT) as a selective reagent was established previously. In this research, the recombinant expression in T. subcordiformis was investigated by particle bombardment with the $r t$-PA gene that encodes the recombinant human tissue-type plasminogen activator (Reteplase), which is a thrombolytic agent for acute myocardial infarction treatment. Transgenic algal strains were selected by their resistance to PPT, and expression of $r t-P A$ was validated by PCR, Southern blotting, and Western blotting, and bioactivity of rt-PA was confirmed by the fibrin agarose plate assay for bioactivity. The results showed that $r t-P A$ was integrated into the genome of T. subcordiformis, and the expression product was bioactive, indicating proper post-transcriptional modification of rt-PA in T. subcordiformis. This report contributes to efforts that take advantage of marine microalgae as cell factories to prepare recombinant drugs and in establishing a characteristic pathway of oral administration in aquaculture.
\end{abstract}

Keywords: algal genetic transformation; recombinant expression; Reteplase; $r t$-PA gene; Tetraselmis subcordiformis; thrombolytic agent

\section{Introduction}

Tetraselmis subcordiformis (Wille) Butcher (= Platymonas subcordiformis) is a common marine unicellular green alga with broad application prospects in aquaculture and bioenergy [1-4]. Due to its high quantities of polysaccharides, proteins, polyunsaturated fatty acids, vitamins, and other nutrient supplements [4-7], T. subcordiformis is widely used in aquaculture as feed for bivalve mollusks, penaeid shrimp larvae, and rotifers [2,8,9]. In addition, T. subcordiformis was shown to photobiologically evolve hydrogen $\left(\mathrm{H}_{2}\right)$, indicating that this alga may also provide a potential sustainable energy source [3].

In earlier research, both stable nuclear and chloroplast transformation systems have been established in T. subcordiformis using glass-bead agitation and the particle bombardment method [10,11]. Among three proven effective exogenous promoters, the transformation rate of the egfp gene in T. subcordiformis driven by CaMV35S and SV40 promoters was higher than that of the CMV promoter [12]. GFP as a reporter gene was successfully expressed in the cytoplasm and chloroplast of T. subcordiformis to display the success of transformation [11-13]. Stable inheritance of a foreign character can be obtained by screening with a resistance gene. T. subcordiformis has been shown to have no sensitivity to streptomycin, kanamycin, spectinomycin, or chloramphenicol, but is highly sensitive 
to the herbicide phosphinothricin (PPT), whose brand name is Basta [10]. The Basta resistance gene bar confers PPT resistance to positive transformants of T. subcordiformis [10]. Therefore, developing T. subcordiformis as a eukaryotic, photoautotrophic, and low-cost cell factory to prepare high value bioactive substances such as recombinant drugs is a promising approach.

Reteplase (rt-PA) is the third generation of thrombolytic agents for treating acute myocardial infarction and structurally a single-chain non-glycosylated deletion mutant of wild-type tissue plasminogen activator (t-PA), consisting of only the Kringle II and protease domain $[14,15]$. The affinity of rt-PA toward fibrin is greater than 600 -fold higher when compared with that of t-PA. Moreover, rt-PA fails to bind with human hepatocellular specific receptors because of the absence of Kringle I and the EGF domain, which prolongs the half-life of rt-PA in blood [16-18]. Although rt-PA is the most effective agent to treat clinical thrombolysis, high preparation costs from incorrect protein folding and disulfide bond modifications in prokaryotic expression systems make preparation of this agent expensive, thereby precluding easy access, especially in developing countries. To reduce the preparation costs, in this study, heterologous expression of the $r t-P A$ gene was investigated in a eukaryotic microalga T. subcordiformis, with bioactivity of the produced recombinant rt-PA evaluated. In addition, the potential of transgenic T. subcordiformis as a new marine bioreactor to produce recombinant drugs and as a characteristic pathway for oral administration in aquaculture is discussed.

\section{Results}

\subsection{Biolistic Transformation and Basta Selection}

The heterologous protein expression vector pSVrPA/CaMVbar constructed in our laboratory was used in this experiment. The herbicide PPT resistance gene bar was driven by the CaMV35S promoter (Figure 1a). The rt-PA protein consists of three modules, namely, integrated His-tag, the Kringle II domain, and the protease domain (Figure 1b), and expression of the $r t-P A$ gene was regulated by the SV40 promoter. Genetic transformation was performed using the particle bombardment method.
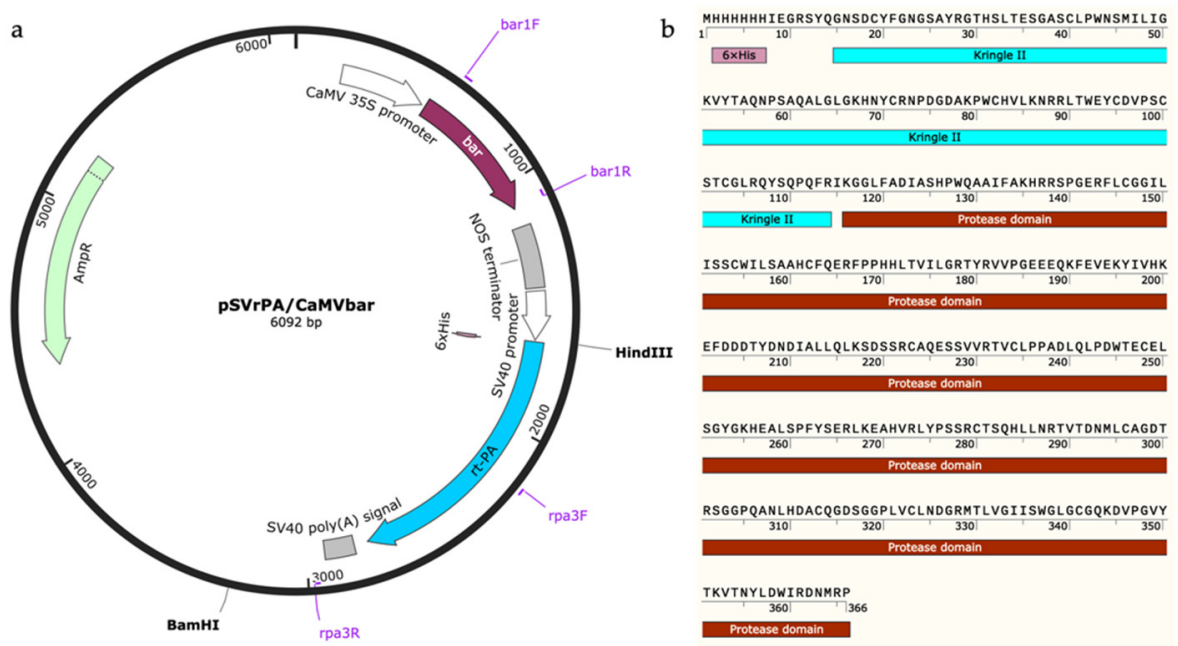

Figure 1. Illustration of plasmid vector pSVrPA/CaMVbar used to transform T. subcordiformis (a) and representation of the rt-PA protein which contains His-tag (pink), Kringle II domain (blue-green), and Protease domain (brown) (b).

Following biolistic transformation and recovery for two days, all bombarded cells were transferred to liquid modified $\mathrm{f} / 2$ medium with $50 \mathrm{mg} \cdot \mathrm{L}^{-1}$ of PPT and cultured for a week. During this selection process, most algal cells died and the color of medium turned from green to white. Then, the medium containing the herbicide was replaced with fresh modified f/2 medium for recovery. About one week later, the medium returned to green 
and approximately $10^{5}$ surviving cells were then transferred and spread on solid modified $\mathrm{f} / 2$ medium with $40 \mathrm{mg} \cdot \mathrm{L}^{-1}$ of PPT. Thousands of colonies appeared after two weeks' incubation (Figure 2a). Twenty-two colonies were selected and cultured in liquid modified $\mathrm{f} / 2$ medium without the addition of the herbicide for further molecular detection. No significant differences in growth or appearance could be observed between resistant and sensitive strains including blank and negative control (Figure $2 b$ ).

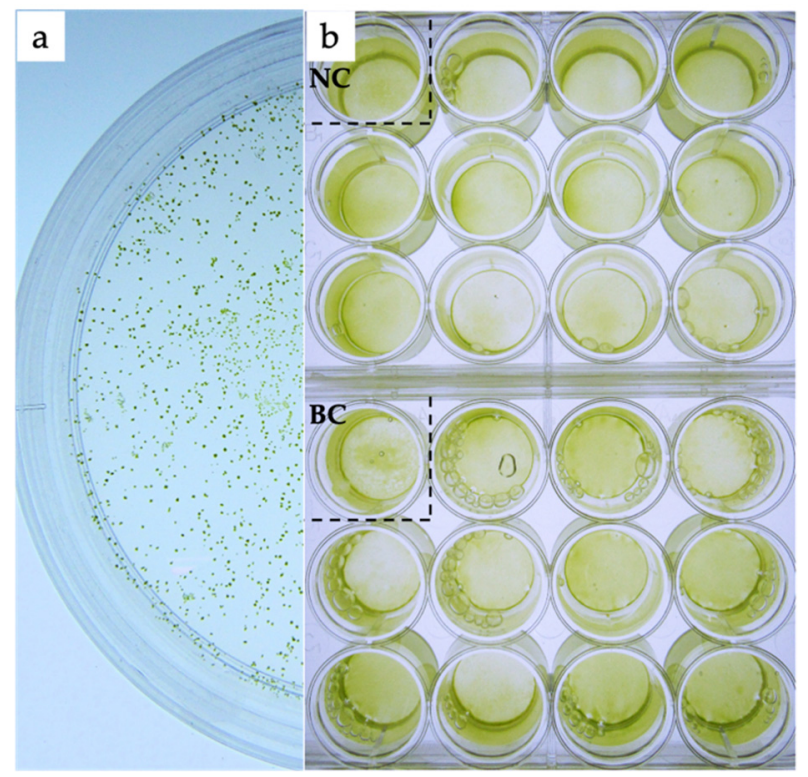

Figure 2. Herbicide PPT screening of transformed T. subcordiformis. (a) The PPT-resistance colonies appeared in solid modified $\mathrm{f} / 2$ medium containing $40 \mathrm{mg} \cdot \mathrm{L}^{-1}$ of PPT; (b) culture of wildtype group, the negative control, and 22 PPT-resistance colonies without herbicide. BC, blank control, wildtype group; NC, negative control, a colony bombarded with gold powders without plasmid DNA.

\subsection{Detection of the bar and $r t-P A$ Gene Integration}

Based on PCR detection results, eight (0310T, A1, A2, B3, B4, R1B1, R1B2, and R1B3) of the 22 colonies selected were detected to be positive with gene amplification of the 491 $\mathrm{bp}$ band of a bar gene fragment using primers bar1F/R (Figure 3a). The positive bands of integrated bar gene appeared faint mainly because the GC content of bar gene is high. Moreover, four colonies, A1, A2, B3, R1B2, showed the target 804 bp band amplified by primers $\mathrm{rpa} 3 \mathrm{~F} / \mathrm{R}$ for a $r t-P A$ gene fragment (Figure $3 \mathrm{~b}$ ). No target bands were detected in the wild-type sample or the negative control, which was transformed with naked golden particles. The four samples with both $b a r$ and $r t-P A$ gene positive signals from PCR detection were analyzed by Southern blotting. The partial gene fragment of $r t-P A$ gene and SV 40 poly(A) terminal signal amplified by primers rpa3F/R was used as the probe for Southern blotting. Total DNA of each sample was digested with endonucleases HindIII and BamHI. An expected hybridization band was detected in all tested samples with no signal observed for the blank control (Figures $3 c$ and S1). The PCR and Southern blotting results showed that $r t-P A$ was stably integrated into the genomes of colonies A1, A2, B3, and R1B2. To verify integration stability of $r t-P A$ gene, B3 samples cultured for proliferation without herbicide PPT at day 9, 34, and 50 were collected. Another B3 sample maintained in $\mathrm{f} / 2$ medium with herbicide PPT for several months was also used. PCR detection using primers rpa3F/R showed that all samples contained $r t-P A$ positive signals. (Figure $3 \mathrm{~d}$ ). 


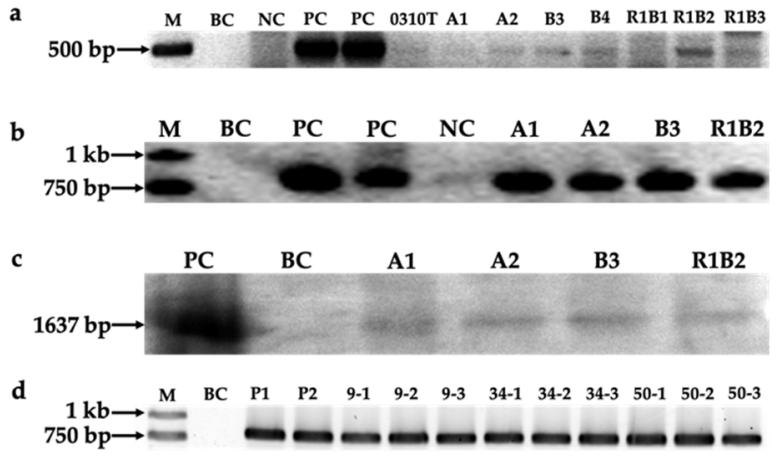

Figure 3. Results of PCR and Southern blotting detection for PPT resistance colonies. (a) PCR detection for bar gene; (b) PCR detection for $r t-P A$ gene; (c) Southern blotting detection for colonies which had positive $r t-P A$ gene signal in PCR detection; (d) PCR detection for $r t$-PA gene integration stability. M, marker; BC, blank control, the genomic DNA of wildtype algae strain; NC, negative control, the genomic DNA of algae strain bombarded with gold particles without plasmid DNA; PC, positive control, enzyme digestion product of plasmid vector pSVrPA/CaMVbar; P1, P2: B3 sample cultured with PPT; 9, 34, 50: B3 sample cultured without herbicide collected at day 9, 34 and 50.

\subsection{Purification of Recombinant Reteplase, Western Blotting and the Fibrinolysis Activity Assay}

The four colonies, A1, A2, B3, and R1B2, were cultured and proliferated in 2 L Erlenmeyer flasks to increase the biomass and for extraction of recombinant rt-PA protein. After the start codon ATG of $r t-P A$, a His-tag containing six histidine CAC codons was designed for affinity purification of recombinant rt-PA. The protein purification results showed that the recombinant protein was successfully transcribed and translated by colonies A1, A2, and B3, and rt-PA was produced as $1.91 \%, 0.82 \%$, and $0.76 \%$ of the total soluble protein amount produced, respectively (Table 1), whereas no recombinant protein was produced by colony R1B2. The results of Western blotting followed by purification of $\mathrm{Ni}^{2+}$ affinity chromatography also demonstrated that recombinant rt-PA was produced by colonies A1, A2, and B3 (Figure 4a). The Western blot of A1 was fainter than that of A2 and B3, probably because a portion of proteins expressed in A1 were folded incorrectly and the $\mathrm{N}$-terminal domain was incorporated into the inside of the protein, which resulted in a change of protein secondary construction, and the reaction between antigen and antibody failed in Western blotting. The bioactivity of recombinant rt-PA was verified using the fibrin agarose plate assay (FAPA) method. FAPA provides a quick, sensitive method to examine fibrinolysis activity. rt-PA converts plasminogen into plasmin, which then degrades fibrin to produce cleared zones. According to the results of FAPA, the transparent circle observed for colonies A2 and B3 showed effective bioactivity of rt-PA produced by T. subcordiformis, and no such activity was observed in blank and negative controls (Figure $4 \mathrm{~b}$ ).

Table 1. Quantitative determination of recombinant rt-PA in transgenic samples.

\begin{tabular}{ccccc}
\hline Samples & $\begin{array}{c}\text { Biomass (Fresh } \\
\text { Weight) }\end{array}$ & Soluble Protein & rt-PA & $\begin{array}{c}\text { Concentration } \\
\left(\mu \mathrm{g} \cdot \mathbf{m g}^{-\mathbf{1}} \text { Soluble }\right. \\
\text { Proteins) }\end{array}$ \\
\hline A1 & $1.93 \mathrm{~g}$ & $23.2 \mathrm{mg}$ & $44.2 \mu \mathrm{g}$ & 1.91 \\
A2 & $2.20 \mathrm{~g}$ & $24.8 \mathrm{mg}$ & $20.4 \mu \mathrm{g}$ & 0.82 \\
B3 & $2.34 \mathrm{~g}$ & $23.6 \mathrm{mg}$ & $17.85 \mu \mathrm{g}$ & 0.76 \\
R1B2 & $1.65 \mathrm{~g}$ & $23.6 \mathrm{mg}$ & - & - \\
\hline
\end{tabular}




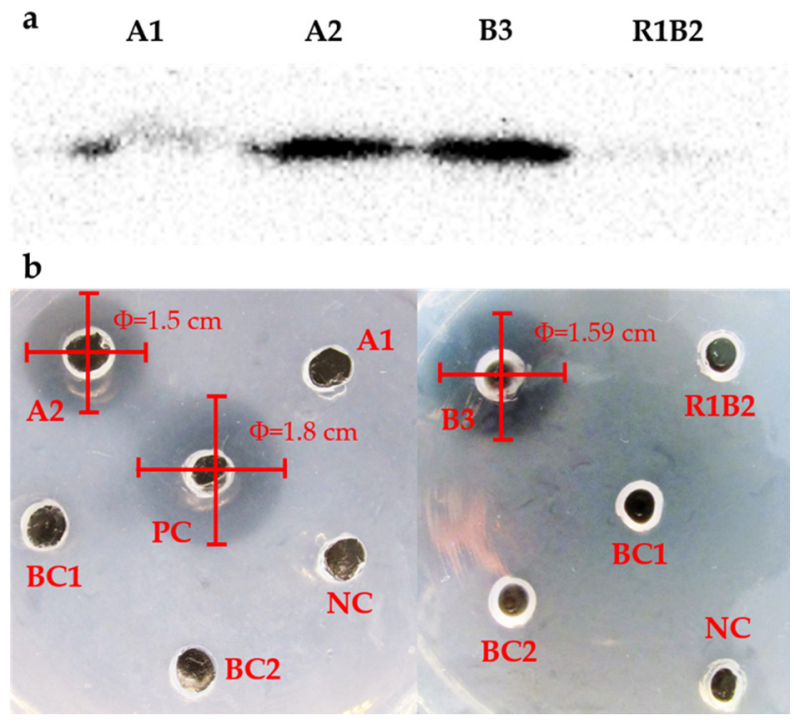

Figure 4. Results of Western blotting and FAPA detection for colonies A1, A2, B3, and R1B2. (a) Results of Western blotting detection; (b) FAPA experiment. BC1, blank control without any reagents in the well; BC2, blank control with PBS (used as protein solvent) in the well; NC, negative control with crude extract of soluble protein of T. subcordiformis in the well; PC, positive control with urokinase in the well.

\section{Discussion}

The results showed that $r t-P A$ was successfully integrated into the genome of T. subcordiformis, and recombinant rt-PA expressed by colonies A2 and B3 showed expected thrombolytic bioactivity, indicating that recombinant rt-PA underwent proper post-translational modification and structural folding in marine microalga T. subcordiformis.

Although a stable nuclear genetic transformation system has been established in T. subcordiformis [10], rigorous screening and detection procedures are essential for obtaining positive transformants that stably express non-native proteins with bioactivity. The bombarded cells were first screened in liquid medium against PPT to remove the majority of untransformed cells. The change in the color of the medium from green to white demonstrated that most cells were killed by this screening step. Subsequently, the second screening on a solid agar plate was performed to obtain a monoclonal algal strain. In this step, $10^{5}$ cells were spread on the solid medium plate and thousands of colonies appeared. Twenty-two colonies were selected from the plate for PCR detection, and only eight colonies yielded a positive bar gene signal, from which only four colonies were found to be positive for the $r t-P A$ gene. These results indicated that the majority of the 22 clones grown on the agar selection plate were herbicide tolerant rather than resistant clones, and co-integration of bar with $r t-P A$ was not a dominant event. Additionally, Western blotting analysis identified a clone, R1B2, without the expected protein product, suggesting potential non-integration of expression regulatory elements, or gene silencing from a position effect. Finally, only two of the three clones, A2 and B3, were confirmed to express recombinant rt-PA with thrombolytic activity by FAPA, indicating that incorrect post-translational modifications may have occurred. The products produced by A1 resulted in loss of bioactivity. Therefore, multiple rounds of screening and detection assays are necessary to achieve engineered microalgal strains with expected bioactivity.

In this study, the average concentration of rt-PA expressed in strains A1, A2, and B3 was $1.16 \mu \mathrm{g} \cdot \mathrm{mg}^{-1}$ soluble protein, which is approximately seven-fold higher than that expressed in gametophytes of the brown macroalga Saccharina japonica, in which $0.159 \mu \mathrm{g} \cdot \mathrm{mg}^{-1}$ soluble protein was produced [19]. Presumably, this is because the protein content of S. japonica was much lower than that of T. subcordiformis. In these three rt-PA protein positive strains, A1 exhibited the highest concentration of $1.91 \mu \mathrm{g} \cdot \mathrm{mg}^{-1}$. However, thrombolytic bioactivity was not detected in this strain. The integrated $r t-P A$ gene of A1 
was sequenced and the coding region did not acquire any mutations. According to results of SDS-PAGE (Figure S2) and Western blot, the recombinant rt-PA was indeed translated in colony A1 and the size of the recombinant protein was correct. Based on the above results, it was suggested that the primary structure of recombinant rt-PA has no mistake. The bioactivity of rt-PA also relies heavily on the secondary structure, particularly the accurate cleavage on the specific site and the correct form of the nine disulfide bond. We inferred that the secondary structure of recombinant rt-PA was not correct in A1. Verification of this hypothesis needs more experimental evidence. Currently, the main preparation method of Reteplase is recombinant expression in Escherichia coli. The recombinant rt-PA prepared using this recombinant expression system is usually produced in inclusion bodies as an inactive form that is only active after in vitro folding [20,21]. The renaturation ratio is relatively low, which contributes to the associated high costs of preparing this drug. Our research showed that using photoautotrophic green microalga, a eukaryotic expression host, to produce bioactive Reteplase is feasible. The recombinant expression product of A2 and A3 strains was bioactive, indicating that produced recombinant rt-PA underwent proper post-translational modification and structural folding in T. subcordiformis.

In addition to using this new marine bio-reactor to produce recombinant drugs, the successful expression of recombinant proteins with complex structures also makes it possible to use microalga to deliver drugs or vaccines though the food chain. T. subcordiformis is a common green microalga living in offshore areas of China. The shape of the cell is compressed and generally 11-16 $\mu \mathrm{m}$ in length, 7-9 $\mu \mathrm{m}$ in width, and 3.5-5 $\mu \mathrm{m}$ in thickness [22]. In addition, T. subcordiformis is enriched with polysaccharides, proteins, fatty acids, and vitamins [4-7]. In view of the above characteristics, this microalga is an easy and suitable prey for larvae of fish, shrimp, and shellfish, and the technology for large-scale cultivation has been established [23]. Currently, antibiotic abuse is a prominent problem in aquaculture [24]. Among the possible solutions to resolve this issue, oral administration of microalgae that contain recombinant antibacterial peptides or vaccines is a promising solution [25].

In conclusion, using the established stable nuclear transformation system, Reteplase with a complex secondary structure encoded by $r t-P A$ was expressed successfully in the marine green microalga $T$. subcordiformis. This research demonstrated that $T$. subcordiformis has potential use as a promising cell factory to prepare bioactive proteins such as recombinant drugs and other substances. To elevate the expression level of Reteplase in T. subcordiformis, more efforts are needed in searching for endogenous stronger promoters, screening more positive transformants, and optimizing conditions of growth and fermentation.

\section{Materials and Methods}

\subsection{Algae Culture}

The strain of T. subcordiformis was provided by Professor Song Xue from Dalian Institute of Chemical Physics, Chinese Academy of Sciences. T. subcordiformis cells were cultured in a modified $\mathrm{f} / 2$ medium [26] at $23^{\circ} \mathrm{C}$ with a $12: 12 \mathrm{~h}$ light:darkness photoperiod under $90-100 \mu \mathrm{mol}$ photons $\mathrm{m}^{-2} \cdot \mathrm{s}^{-1}$ irradiance. The culture density was measured using a hemocytometer and cells for genetic transformation were harvested at the mid-log phase.

\subsection{Plasmid Vector for Transformation}

The heterologous protein expression vector $\mathrm{pSVrPA} / \mathrm{CaMVbar}$ constructed in our laboratory was used [19]. The vector was maintained and amplified in E. coli Top10 strain. Plasmid DNA was isolated from E. coli with a TIANpure Midi Plasmid Kit (Tiangen, Beijing, China).

\subsection{Biolistic Transformation}

Genetic transformation was performed using a Biolistic PDS-1000/He Particle Delivery System (Bio-Rad, Hercules, CA, USA). Before bombardment, T. subcordiformis at log phase were collected by centrifugation at $6000 \mathrm{rpm}$ (approximately $3500 \times g$ ) for $5 \mathrm{~min}$. 
Approximately $1 \times 10^{8}$ cells were then spread onto the central area of $\mathrm{f} / 2$ medium agar plates to a diameter of $2 \mathrm{~cm}$. According to the operation protocol described by Cui et al. [12], the transformation vector was adhered onto gold particles (1.0 $\mu \mathrm{m}$ in diameter), and the same parameters described in this protocol were followed, including the 900 psi of rupture disk pressure and a particle travel distance of $6 \mathrm{~cm}$. After transformation, plates were placed in darkness for $8 \mathrm{~h}$ for recovery. A plate bombarded with gold powder without plasmid DNA was used as a negative control. All experiments were performed in triplicate.

\subsection{Basta Selection for Positive Transformants}

After two days of culture, transformed cells were transferred to the selective liquid modified $\mathrm{f} / 2$ medium with $60 \mathrm{mg} \cdot \mathrm{L}^{-1}$ of Basta and cultured for a week. Surviving cells were then spread on solid modified $\mathrm{f} / 2$ medium agar plates with $40 \mathrm{mg} \cdot \mathrm{L}^{-1}$ of Basta. Colonies appearing after two weeks were selected and streaked on agar plates of modified $\mathrm{f} / 2$ medium with $20 \mathrm{mg} \cdot \mathrm{L}^{-1}$ Basta. After another two weeks of cultivation, 22 colonies were selected and cultured in the liquid modified $\mathrm{f} / 2$ medium without the addition of the herbicide.

\subsection{PCR Detection and Southern Blotting}

After two weeks of cultivation in liquid medium without the selection pressure of the herbicide, cells originating from selected resistant colonies were harvested and genomic DNA was extracted using a plant genomic DNA kit (Tiangen, Beijing, China). According to the sequence of vector $\mathrm{pSVrPA} / \mathrm{CaMVbar}$, primers bar1F (5'-TCTGCACCATCGTCAACCACTACA-3'), bar1 $\mathrm{R}$ (5'-TCAAATCTCGGTGACGGGCAGGAC-3'), rpa3F (5'-TCTTGGGCAGAACATACC-3'), and rpa3R ( $5^{\prime}$-TCCCCCTGAACCTGAAAC-3') were designed to amplify the specific $b a r$ and $r t-P A$ gene fragments by PCR. PCR products were visualized using gel electrophoresis in a $1.2 \%$ agarose gel stained with Super GelRed (US Everbright Inc., Suzhou, China). The probe of $r t-P A$ gene for Southern blotting was synthesized using the $804 \mathrm{bp} \mathrm{PCR} \mathrm{fragment}$ amplified by primers rpa3F/R. Total genomic DNA (about $10 \mu \mathrm{g}$ ) of each sample was digested with endonucleases HindIII and BamHI (New England Biolabs, Ipswich, MA, USA). Probe synthesis and Southern blotting were conducted with a DIG DNA labeling and detection kit (Roche, Mannheim, Germany).

\subsection{Purification of Recombinant Reteplase and Western Blotting}

Positive transformants transformed with $\mathrm{pSVrPA} / \mathrm{CaMVbar}$ were frozen in liquid nitrogen and then homogenized using a plant tissue grinder Tissuelyser-48 (Jingxin, Shanghai, China) with a vibration frequency of $70 \mathrm{~Hz}$. The duration time was $90 \mathrm{~s}$ and the homogenizing process was repeated three times. Then, $200 \mu \mathrm{L}$ extraction buffer consisting of $10 \mathrm{mM}$ Tris ( $\mathrm{pH} 8.0$ ), $0.02 \% \mathrm{NaN}_{3}$, and $0.001 \%$ PMSF was added to $1.5 \mathrm{~mL}$ microcentrifuge tubes with homogenates from $100 \mathrm{mg}$ fresh thalli. The mixture was centrifuged at $12,000 \times \mathrm{g}$ for $15 \mathrm{~min}$ at $4{ }^{\circ} \mathrm{C}$ and the supernatants were transferred to new microcentrifuge tubes and stored on ice for further use. The total soluble protein concentration was determined by using the Bradford Protein Assay Kit (Tiangen, Beijing, China).

To purify expressed rt-PA, the prepared supernatants were mixed with $30 \mathrm{~mL}$ binding buffer ( $20 \mathrm{mM} \mathrm{NaPO}_{4}, 500 \mathrm{mM} \mathrm{NaCl}$, and $20 \mathrm{mM}$ imidazole, $\mathrm{pH}$ 7.4), and loaded onto a pre-equilibrated column of Chelating Sepharose (GE Healthcare BioScience, Marlborough, MA, USA) charged with $\mathrm{Ni}^{2+}$. The column was washed with washing buffer $(20 \mathrm{mM}$ $\mathrm{NaPO}_{4}, 500 \mathrm{mM} \mathrm{NaCl}$, and $100 \mathrm{mM}$ imidazole, $\mathrm{pH}$ 7.4) to remove miscellaneous proteins. rt-PA was eluted with elution buffer $\left(20 \mathrm{mM} \mathrm{NaPO}_{4}, 500 \mathrm{mM} \mathrm{NaCl}\right.$, and $500 \mathrm{mM}$ imidazole, $\mathrm{pH}$ 7.4). The imidazole was removed by using a Sephadex G25 column. The peak fraction was collected and concentrated by ultrafiltration.

The expression of recombinant protein was analyzed by $12 \%$ sodium dodecyl sulfatepolyacrylamide gel electrophoresis and Western blotting. After electrophoresis, the proteins were transferred onto a polyvinylidene fluoride membrane using the Trans-Blot ${ }^{\circledR}$ SD semi-dry blotting system (Bio-Rad), with a constant voltage of $15 \mathrm{~V}$ for $60 \mathrm{~min}$ at room 
temperature. The blotted membrane was then blocked in 5\% skimmed milk powder solution for $60 \mathrm{~min}$. Subsequently, the membrane was incubated in a solution containing HRP Conjugated Anti His-Tag Mouse Monoclonal Antibody (CWBIO, Beijing, China) for $2 \mathrm{~h}$ at room temperature, and finally was dyed with HRP-DAB agent (Tiangen, Beijing, China) for $5 \mathrm{~min}$.

\subsection{Fibrinolysis Activity Assay}

The bioactivity of purified rt-PA was measured using a modified fibrin agarose plate assay (FAPA) method [19]. The prepared fibrin agarose plate was prepared with 1.0\% agarose, $1 \mathrm{mg} \cdot \mathrm{mL}^{-1}$ bovine fibrinogen, and $0.1 \mathrm{U} \cdot \mathrm{mL}^{-1}$ bovine thrombin in PBS ( $\mathrm{pH}$ 7.4). Holes with diameters of 2-4 mm were made in the plate using an Oxford cup. In each hole, $20 \mu \mathrm{L}$ PBS ( $\mathrm{pH}$ 7.4) containing $0.04 \mathrm{U}$ bovine plasminogen and urokinase or purified protein was added and followed by incubation for $16 \mathrm{~h}$ at $37^{\circ} \mathrm{C}$. Bovine fibrinogen, thrombin, plasminogen, and urokinase were obtained from the National Institute for the Control of Pharmaceutical and Biological Products (NICPBP, Beijing, China). Two blank controls were used in the FAPA experiment: an empty well without any reagents (BC1) and a well filled with PBS (used as protein buffer) (BC2). The negative control was crude soluble protein extract from T. subcordiformis. Urokinase was used as a positive control.

Supplementary Materials: The following are available online at https: / www.mdpi.com/article / 10.3390/md19060315/s1, Figure S1. Southern blotting detection for colonies A1, A2, B3 and R1B2. Figure S2. The SDS-PAGE gel of colony A1, A2 and B3.

Author Contributions: Conceptualization, P.J. and C.W.; methodology, P.J., C.W., C.Z. and J.W.; validation, P.J. and C.W.; formal analysis, C.W.; investigation, P.J. and C.W.; resources, P.J.; data curation, P.J. and C.W.; writing—original draft preparation, C.W.; writing—review and editing, C.W. and P.J.; supervision, P.J.; project administration, P.J.; funding acquisition, P.J. and C.W. All authors have read and agreed to the published version of the manuscript.

Funding: This research was supported by the National Key R\&D Program of China (2018YFD0901500), National Natural Science Foundation of China (41806165), Key R\&D Program of Shandong Province (2019GSF107012), China Postdoctoral Science Foundation (2018M642711), and Postdoctoral Application Research Program funded by Qingdao (2018059).

Institutional Review Board Statement: Not applicable.

Informed Consent Statement: Not applicable.

Data Availability Statement: The data presented in this study are available within this article and supplementary materials.

Acknowledgments: The authors appreciate the assistance of engineer Fu Deng from Institute of Oceanology, Chinese Academy of Sciences in the operation of Bio-Rad Biolistic PDS-1000/He Particle Delivery System.

Conflicts of Interest: The authors declare no conflict of interest.

\section{References}

1. Yang, X.; Qiu, Z.; Zhan, D.; Jian, Y.; Ye, H. Study on the applying of dried Platymonas sp. in the seed rearing of the bay scallop. Shandong Fish. 2003, 20, 37-39.

2. Zheng, Y.; Wang, G.; Li, S. Impacts of Phaeodactylum tricornutum and Platymonas subcordiformis on fecundity, survival and fatty acid of Apocyclops borneoensis. J. Xiamen Univ. 2012, 51, 402-409.

3. Guan, Y.; Deng, M.; Yu, X.; Zhang, W. Two-stage photo-biological production of hydrogen by marine green alga Platymonas subcordiformis. Biochem. Eng. J. 2004, 19, 69-73. [CrossRef]

4. Yao, C.; Ai, J.; Cao, X.; Xue, S.; Zhang, W. Enhancing starch production of a marine green microalga Tetraselmis subcordiformis through nutrient limitation. Bioresour. Technol. 2012, 118, 438-444. [CrossRef] [PubMed]

5. Wang, L.; Chen, R.; Zhuang, H.; Ou, L.; Huang, X. FT Raman spectra study of Platymonas subcordiformis. Spectrosc. Spectr. Anal. 2007, 27, 81-83.

6. Xu, D.; Gao, Z.; Li, F.; Fan, X.; Zhang, X.; Ye, N.; Mou, S.; Liang, C.; Li, D. Detection and quantitation of lipid in the microalga Tetraselmis subcordiformis (Wille) Butcher with BODIPY 505/515 staining. Bioresour. Technol. 2013, 127, 386-390. [CrossRef] 
7. Ma, R.; Wang, B.; Chua, E.T.; Zhao, X.; Lu, K.; Ho, S.; Shi, X.; Liu, L.; Xie, Y.; Lu, Y.; et al. Comprehensive utilization of marine microalgae for enhanced co-production of multiple compounds. Mar. Drugs 2020, 18, 467. [CrossRef]

8. Borowitzka, M.A. Microalgae for aquaculture: Opportunities and constraints. J. Appl. Phycol. 1997, 9, 393-401. [CrossRef]

9. Muller-Feuga, A. The role of microalgae in aquaculture: Situation and trends. J. Appl. Phycol. 2000, 12, 527-534. [CrossRef]

10. Cui, Y.; Jiang, P.; Wang, J.; Li, F.; Chen, Y.; Zheng, G.; Qin, S. Genetic transformation of Platymonas (Tetraselmis) subcordiformis (Prasinophyceae, Chlorophyta) using particle bombardment and glass-bead agitation. Chin. J. Oceanol. Limnol. 2012, 30, 471-475. [CrossRef]

11. Cui, Y.; Qin, S.; Jiang, P. Chloroplast transformation of Platymonas (Tetraselmis) subcordiformis with the bar gene as selectable marker. PLoS ONE 2014, 9, e98607. [CrossRef]

12. Cui, Y.; Qu, L.; Zhao, J.; Qin, S. Transient expression of the enhanced green fluorescence protein (egfp) gene in Tetraselmis subcordiformis (Chlorodendrales, Chlorophyta) with three exogenous promoters. Phycologia 2016, 55, 564-567. [CrossRef]

13. Cui, Y.; Wang, J.; Jiang, P.; Bian, S.; Qin, S. Transformation of Platymonas (Tetraselmis) subcordiformis (Prasinophyceae, Chlorophyta) by agitation with glass beads. World J. Microb. Biot. 2010, 26, 1653-1657. [CrossRef]

14. Pennica, D.; Holmes, W.E.; Kohr, W.J.; Harkins, R.N.; Vehar, G.A.; Ward, C.A.; Bennett, W.F.; Yelverton, E.; Seeburg, P.H.; Heyneker, H.L.; et al. Cloning and expression of human tissue-type plasminogen activator cDNA in E. coli. Nature 1983, 20, 214-221. [CrossRef] [PubMed]

15. Kohnert, U.; Rudolph, R.; Verheijen, J.H.; Jacoline, E.; Weening-Verhoeff, D.; Anne, S.; Ulrich, O.; Ulrich, M.; Helmut, L.; Heinrich, P. Biochemical properties of the kringle 2 and protease domains are maintained in the refolded t-PA deletion variant BM 06.022. Protein. Eng. Des. Sel. 1992, 5, 93-100. [CrossRef] [PubMed]

16. Stürzebecher, J.; Neumann, U.; Kohnert, U.; Kresse, G.B.; Fischer, S. Mapping of the catalytic site of CHO-t-PA and the t-PA variant BM 06.022 by synthetic inhibitors and substrates. Protein Sci. 1992, 8, 1007-1013. [CrossRef] [PubMed]

17. Richard, W.S. Molecular biology of plasminogen activators: What are the clinical implications of drug design. Am. J. Cardiol. 1996, $78,2-7$.

18. Noble, S.; McTavish, D. Reteplase: A review of its pharmacological properties and clinical efficacy in the management of acute myocardial infarction. Drugs 1996, 52, 589-605. [CrossRef] [PubMed]

19. Zhang, Y.; Jiang, P.; Gao, J.; Liao, J.; Sun, S.; Shen, Z.; Qin, S. Recombinant expression of rt-PA gene (encoding Reteplase) in gametophytes of the seaweed Laminaria japonica (Laminariales, Phaeophyta). Sci. China Ser. C Life Sci. 2008, 51, 1116-1120. [CrossRef]

20. Harris, T.J.; Patel, T.; Marston, F.A.; Little, S.; Emtage, J.S.; Opdenakker, G.; Volckaert, G.; Rombauts, W.; Billiau, A.; De Somer, P. Cloning of cDNA coding for human tissue-type plasminogen activator and its expression in Escherichia coli. Mol. Biol. Med. 1986, 3, 279-292.

21. Liao, J.; Zhang, J.; Shen, Z. Cloning and expression of tissue-type plasminogen activator mutant Reteplase (r-PA) in E. coli (in Chinese with English abstract). Pharma Biotechnol. 2002, 9, 95-98.

22. Liu, Y.; Chen, Z.; Lu, H.; Liu, C.; Jin, M.; Guo, Z.; Zhang, W. Optimization of culture medium and photosynthetic characteristics of Platymonas subcordiformis. Chin. J. Process Eng. 2007, 7, 1197-1201.

23. Xie, J.; Zhang, Y.; Li, Y.; Wang, Y. Mixotrophic cultivation of Platymonas subcordiformis. J. Appl. Phycol. 2001, 13, 343-347. [CrossRef]

24. Han, P.; Lu, Q.; Fan, L.; Zhou, W. A review on the use of microalgae for sustainable aquaculture. Appl. Sci. $2019,9,2377$. [CrossRef]

25. Shi, Q.; Chen, C.; Zhang, W.; Wu, P.; Sun, M.; Wu, H.; Wu, H.; Fu, P.; Fan, J. Transgenic eukaryotic microalgae as green factories: Providing new ideas for the production of biologically active substances. J. Appl. Phycol. 2021, 33, 705-728. [CrossRef]

26. Guillard, R.R.L.; Ryther, J.H. Studies of marine planktonic diatoms. I. Cyclotella nana Hustedt and Detonula confervacea Cleve. Can. J. Microbiol. 1962, 8, 229-239. 